\title{
STRATEGI PERBANKAN SYARIAH DALAM MANAJEMEN ASET DAN LIABILITAS
}

\author{
Rani Raranta \\ Ekonomi Syariah-Program Pasca Sarjana-Institut Agama Islam Negeri \\ Batusangkar \\ Email: raniraranta96@gmail.com
}

\begin{abstract}
The purpose of this article is for readers to know what Islamic banking strategies are in managing their assets and liabilities. This research is classified as Library Research, while the nature of this research is descriptive qualitative, namely research that seeks to find solutions to existing problems based on data, by presenting, analyzing, and interpreting data. Data analysis techniques that take general things, then conclude to specific things. The results of this study can be concluded that if Islamic banks are able to maximize their benefits from wellmanaged and structured funding and financing and are able to produce optimal management of the risks faced by Islamic banks, then these Islamic banks can be said to be successful in their asset and liability management strategies. The ALMA strategy used by Islamic banks is Planning, Fund Management and Financing. The ALMA Strategy Quality Management can also minimize risks such as: Financing Risk, Liquidity Risk, Pricing Risk, Foreign Exchange Risk, Contingency Risk, Liquidity Risk, Gap Risk.
\end{abstract}

Kata Kunci: Strategi, Aset, Liabilitas, resiko.

\section{PENDAHULUAN}

Pendapatan laba yang tinggi dan resiko yang kecil merupakan target perusahaan dalam mempertahankan perusahaannya, semakin tinggi pendapatan perusahaan tersebut maka semakin kuat perusahaan dalam menentukan harga pasar baik dalam bidang lending maupun funding, secara umum dan ekuitas perusahaan. Kemampuan perusahaan tersebut bisa digunakan dengan managemen aset dan liabilitas yang biasa disebut dengan ALMA (Asset and Liability Management), yang merupakan sisi dua neraca dimana sisi pasiva yang menggambarkan sumber dana dan sisi aktiva yang menggambarkan penggunaan dana harus dikelola 
secara efisien, efektif, produktif secara optimal (Rivai, 2007: 372).

Asset dan liabilitas pada setiap bank ini dikelola oleh Assets dan Liability Committee (ALCO) yang secara organisasi tidak terlihat dalam struktur organisasi, namun kegiatannya ada dan dikelola dalam team work serta secara operasional umumnya berada di dalam divisi treasury, yang dipimpin oleh wakil direktur utama/direksi yang membidangi divisi treasury dan kepala divisi treasury umumnya sebagai ketua pelaksana. Asset and Liability Management ini juga untuk mengelola risiko-risiko yang kemugkinan timbul dalam kegiatan bisnis sehari-hari yang dirancang sedemikian rupa sehingga dapat mengoptimalkan pendapatan sekaligus membatasi risiko assets dan liabilities dengan mematuhi ketentuan kebijakan moneter dan pengawasan bank melalui suatu organisasi (Rivai, 2010: 534).

Potensi risiko yang dihadapi oleh bank konvensional juga dihadapi oleh bank syariah, kecuali risiko tingkat bunga, karena bank syariah tidak menggunakan prinsip bunga melainkan prinsip profit and loss sharing yang menjadi sistem operasionalnya, disisi yang lain perbankan syariah memiliki karakteristik yang berbada dengan bank konvensional yakni kegiatan bisnis yang hanya ada pada perbankan syariah seperti perdagangan dan gadai sehingga hal tersebut membawa dampak teknis yang luas pada aktifitas perbankan salah satunya adalah pengelolaan assetliability. Berbicara mengenai sistem manajemen aset tidak terlepas dari manajemen liabilitas. Dua sistem tersebut ibarat dua sisi mata uang yang saling terhubung satu sama lain. Penyebabnya ialah sebagian besar sumber aset bank syariah diperoleh dari deposit (simpanan), walaupun bank syariah memiliki modal sendiri tetapi kewajibannya lebih dominan dari modal sendiri. Akibatnya pengembangan aset dipengaruhi oleh meningkatnya liabilitas. Jadi yang menjadi focus atau bahasan dari artikel saya yaitu terkait strategi apa yang digunakan perbankan syariah dalam memanajmen asset dan liabilitasnya agar terhindar dari resikoresiko yang mungkin timbul.

\section{KAJIAN PUSTAKA}

\section{Asset}

Asset adalah sesuatu yang mampu menimbulkan aliran kas positif atau manfaat ekonomi lainnya, baik dengan dirinya maupun dengan asset lain, yang hanya didapat oleh Bank Islam sebagai hasil dari transaksi atau peristiwa di masa lalu. Untuk bisa digambarkan sebagai sebuah asset pada pernyataan posisi keuangan Bank Islam, asset itu harus memiliki karakter tambahan sebagai berikut:

1. Dapat diukur secara keuangan dengan tingkat reliabilitasyang wajar. 
2. Tidak boleh dikaitkan dengan kewajiban yang tidak dapat diukur atau hak bagi pihak lain.

3. Bank Islam harus mendapatkan hak untuk menahan, menggunakan atau mengelola asset (Antonio, 2001).

Susilo (2000), mengatakan bahwa aset yang dimiliki sebuah bank bergantung pada beberapa aspek yaitu:

1. Likuiditas dan jangka waktu

2. Resiko

3. Red of return

4. Biaya bunga

5. Diversifikasi

6. Portofolio dan kaitannya dengan penghimpunan dana.

\section{Liabilitas}

Liabilitas adalah kewajiban yang berjalan untuk memindahkan aset, meneruskan penggunaannya, atau menyediakan jasa bagi pihak lain di masa depan sebagai hasil dari transaksi atau peristiwa di masa lalu. untuk bisa digambarkan sebagai sebuah liabilitas pada pernyataan posisi keuangan Bank Islam, liabilitas itu harus memiliki karakter tambahan sebagai berikut:

1. Bank Islam harus memiliki kewajiban kepada pihak lain dan kewajiban Bank Islam tidak boleh saling bergantung dengan kewajiban pihak lain kepada bank.

2. Kewajiban Bank Islam harus bisa diukur secara keuangan dengan tingkat reabilitas yang wajar.

3. Kewajiban Bank Islam itu harus bisa dipenuhi melalui pemindahan satu atau lebih aset Bank Islam kepada pihak lain, meneruskan kepada pihak lain akan penggunaan aset Bank Islam untuk suatu periode atau menyediakan jasa pihak lain (Antonio, 2000).

Dalam konsep dasar liabilitas perbankan terdapat tiga hal pokok yang perlu mendapat perhatian yaitu:

1. Bank berusaha untuk memperkecil biaya dananya

2. Bank berusaha memenuhi komitmen pemberian kredit kepada nasabah nasabahnya

3. Bank berusaha menghindari namun tidak melanggar peraturan peraturan yang berlaku yang akan menimbulkan beban kepada bank.

Liabilitas atau penghimpunan dana perlu memperhatikan beberapa aspek berikut:

1. Biaya administrasi

2. Biaya bunga

3. Strategi, cara atau metode

4. Diversifikasi

5. angka waktu dan likuiditas

6. Portofolio dan kaitanya dengan penggunaan dana (Susilo, 2000). 
Siamat (1999), menambahkan bahwa liabilitas perbankan syariah dipengaruhi oleh beberapa hal antara lain:

1 Kepercayaan masyarakat pada suatu bank jelas akan mempengaruhi kemampuan bank untuk menghimpun dana dari berbagai sumber terutama dari masyarakat atau institusi. Tingkat kepercayaan masyarakat ini sangat dipengaruhi oleh kinerja bank yang bersangkutan, posisi keuangan, kapabilitas, integritas serta kredibilitas para manajer bank.

2 Ekspektasi, yaitu perkiraan pendapatan yang akan diterima oleh penabung dibandingkan dengan alternatif investasi lain dengan tingkat resiko yang sama.

3 Keamanan, yaitu jaminan keamanan oleh bank atas dana yang disimpan oleh nasabah.

4 Ketetapan waktu, yaitu pengembalian pengembalian simpanan nasabah yang harus selalu tepat waktu.

5 Pelayanan yang lebih tepat dan fleksibel.

6 Pengelolaan dana bank yang hatihati.
Fokus Manajemen Asset Dan Liabilitas

Fokus manajemen aset dan liabilitas adalah mengkoordinasikan portofolio aset liabilitas bank dalam rangka memaksimalkan profit bagi bank dan hasil yang dibagikan kepada para pemegang saham dalam jangka panjang dengan memperhatikan kebutuhan likuiditas dan kehati-hatian (Antonio, 2001).

Prastomiyono

mengatakan bahwa fokus atau tujuan manajemen aset dan liabilitas adalah mengoptimalkan pendapatan dan menjaga agar resiko tidak melampaui batas yang dapat ditolerir, disamping juga memaksimalkan harga pasar dari ekuitas perusahaan. Sedang menurut Bambang (2000) manajemen aset dan liabilitas mempunyai fungsi dan kebijakan dalam menjalankan strategi penentuan harga, baik dalam bidang lending maupun funding.

\section{Asset and Liability Management}

Asset adalah sebuah sumber daya yang dimiliki atau dikendalikan oleh perusahaan sebagai akibat dari peristiwa masa lalu dan dari mana beberapa manfaat ekonomi masa depan dapat diharapkan mengalir ke perusahaan. Kepemilikan aset itu sendiri adalah tidak berwujud. Namun, aset yang 
dimiliki dapat berwujud atau tidak berwujud. Manajemen Asset didefinisikan menjadi sebuah proses pengelolaan segala sesuatu baik berwujud dan tidak berwujud yang memiliki nilai ekonomik, dan mampu mendorong tercapainya tujuan dari individu dan organisasi. Melalui proses manajemen yaitu POLC (Planning, Organizing, Leading dan Controling) agar dapat dimanfaatkan atau dapat mengurangi biaya (cost) secara effisien dan efektif.

Liabilitas atau utang adalah kewajiban membayar kepada pihak lain yang disebabkan oleh tindakan/transaksi sebelumnya. Berdasarkan jangka waktu pelunasannya, manajemen liabilitas merupakan kemampuan bank dalam menyediakan dana yang cukup untuk memenuhi semua kewajibannya maupun komitmen yang telah dikeluarkan kepada nasabah. Sedangkan ALMA adalah manajemen struktur neraca bank dengan tujuan untuk memaksimalkan pendapatan, mengendalikan biaya dalam batasbatas risiko tertentu (Rivai, 2007: 373).

Di dalam buku yang lain, ALMA adalah suatu proses dari perencanaan, pengorganisasian, dan pengawasan yang berfungsi sebagai pengendalian aktiva dan pasiva secara terpadu yang saling berhubungan dalam usaha mencapai keuntungan bank (Karim, 2010: 451).

ALMA merupakan manejemen struktur neraca bank dengan tujuan untuk mengoptimalkan pendapatan dan meminimalkan biaya dalam batas-batas risiko tertentu. Risikorisiko ALMA dalam suatu bank pada umumnya berupa:

1. Financing risk, yaitu debitur akan memenuhi kewajibannya (keterlambatan angsuran atau pelunasan) tepat pada waktunya. Risiko kredit dapat menimbulkan risiko likuiditas.

2. Liquidity risk, yaitu risiko bahwa bank tidak dapat memenuhi kewajibannya pada waktunya atau hanya dapat memenuhi kewajiban melalui pinjaman darurat (bagi hasil yang tinggi) dan atau menjual aktivanya dengan harga yang rendah.

3. Pricing risk, yaitu risiko kerugian dengan akibat perubahan tingkat bagi hasil, menentukan bentuk penurunan margin dari penanaman atau kerugian sebagai akibat menurunnya nilai aktiva. Risiko ini sebagai akibat Net Interest Margin (NIM) atau tidak terpenuhinya likuiditas, atau terjadinya gap karena tidak tepatnya perhitungan pricing atas aset dan liabilitas.

4. Foreign exchange risk, yaitu risiko kerugian sebagai akibat perubahan 
tingkat kurs terhadap "open Sementara itu, pengelolaan sumber position" karena adanya pergerakan dana secara keseluruhan adalah kurs yang merugikan.

5. Gap risk, yaitu risiko kerugian dari ketidakseimbangan interest rate maturity karena adanya pergerakan tingkat bunga yang merugikan.

Liability Management ini yang terbagi tiga bagian, yaitu :

1. Pengelolaan sumber dana yang berasal dari pihak ketiga yang disebut Deposit Management

6. Kontinjen risk, yaitu risiko yang timbul sebagai akibat transaksi kontinjen, contohnya bank garansi dan kontrak valuta asing berjangka.

7. Risiko likuiditas adalah risiko yang ada diperbankan yang biasanya timbul dari cara bank mengelola primary dan secondary rerserve serta pendanaannya sehari-hari

(Tanjung, 2016: 163).

Risiko yang ada dalam pengelolaan primary rererve dapat berupa:

a. Reserve yang dikelola terlalu tinggi dari yang dibutuhkan.

b. Reserve requirement tidak dapat dipenuhi sehingga berakibat dikenakan penalti atau sanksi oleh Bank Indonesia serta timbulnya masalah bagi bank sendiri.

\section{Ruang Lingkup Manajemen Asset dan Liabilitas}

Manajemen dana mencakup semua kegiatan bank yang dapat dilihat dalam pos-pos sisi aktiva maupun pasiva. Pengelolaan dana dari sisi asset ataupun aktiva lazim di 2. Dana yang berasal dari pihak kedua disebut Borrowing

3. Pengelolaan dana yang berasal dari modal sendiri yang disebut Capital Management

Perkembangan ekonomi dan moneter yang berfruktuasi serta persaingan bisnis antarbank yang sangat ketat berpengaruh langsng terhadap manajemen asset dan liabilitas. Keadaan tersebut menyebabkan timbulnya dilema dalam pengelolaannya pada bank, yaitu antara mengutamakan pofitabilitas di satu sisi dan likuiditas atau keamanan disisi lain. Beberapa alasan perlunya asset dan liabiltas dikelola:

1. Tingkat suku bunga

2. Perubahan struktur sumber dana

3. Meningkatnya kebutuhan modal

4. Persaingan yang ketat antar bank

5. Perkembangan sistem informasi

6. Meningkatnya peran pemerintah

7. Ketersediaan dana di pasar uang

8. Perubahan komposisi aktiva

9. Bermunculannya berbagai lembaga keuangan 
Hubungan Manajemen Asset \& Liabilitas (ALMA) dengan Asset Liability Committe (ALCO)

Produksi dalam industri perbankan adalah aktivitas bank yang tercermin dalam neraca asset/liability sementara hasil produksi adalah laporan laba/rugi. Hasil produksi yang optimal dapat dicapai jika para pejabat bank syariah mampu mempersiapkan perencanaan dan pengaturan penghimpunan dan pengalokasian dana. Oleh karena itu, perencanaan dan pengaturan dana akan berjalan baik harus dilakukan oleh pihak atau badan ynag baik. Badan ini biasanya berbentuk tim atau panitia atau disebut commitee ataupun dewan khusus. Dewan khusus atau tim yang mengelola manajemen dana atau lebih luas lagi pada pengelolaan asset and liability of bank, disebut dengan Asset and Liability Commitee Atau disingkat (ALCO) (Rivai, 2010: 546-547).

Sesuai dengan namanya panitia atau tim ini melakukan kegiatan rutin dan mengadakan pertemuan yang juga diatur secara rutin, misalnya sebulan sekali atau sebulan dua kali. Keberhasilan proses manajemen Asset liability (ALMA) tergantung pada koordinasi serta partisipasi seluruh bagian-bagian yang terlibat dalam komite untuk menangani masalah-masalah yang menjadi tanggung jawabnya. Agar strategi ALMA dapat efektif, maka beberapa kriteria berikut harus dipenuhi oleh tim atau ALCO, yaitu:

1. Semua angggota ALCO harus terlibat dan mengerti bahwa strategi ALMA adalah strategi menyeluruh dari asset dan liability.

2. Semua anggota ALCO harus terlibat dalam pencapaian anggaran yang direncanakan.

3. Semua anggota ALCO harus berfokus kepada hasil mendatang serta memberikan saran dan pendaapat pemecahan.

4. Semua anggota ALCO harus saling berhubungan dalam kaitannya dalam pencapaian tujuan.

5. ALCO harus merupakan keterpaduan dari seluruh bagian yang ada di bank. Semua bagian harus mempunyai sistem yang mampu memberikan informasi yang tepat, terbaru dan tepat.

6. Semua anggota ALCO harus mempunyai semangat pembaharuan, mengetahui kemungkinan- kemungkinan yang akan terjadi serta mampu mengantisipasi kemungkinan yang akan terjadi.

ALMA (Asset Liability Management) dalam suatu bank syariah merupakan strategi dan pembuatan kebijakan. Dengan demikian, ALMA pada dasarnya adalah proses perencanaan. Oleh karena itu, beberapa strategi penting 
yang terlibat dalam Proses ALMA adalah:

1. Perencanaan

Hubungan ALMA dengan perencanaan karena:

a. Dalam proses pengambilann keputusan harus diketahui ke arah mana tujuan yang diinginkan

b. Dalam proses pengambilan keputusan jangka panjang harus diketahui akibatnya terhadap pencapaian keuntungan, termasuk keadaan likuiditas, keadaan profit rate. Oleh kerena itu, perencanaan merupakan strategi ALMA.

2. Manajemen Dana

Manajemem dana merupakan salah satu pengelola strategi ALCO dimana apabila perencanaan sebagai strategi dasar, maka manajemen dana sebagai pengelola operasional maka harus dijaga kontinuitas penggunaann serta sumber dananya, secara tepat, baik dari sisi jumlah, waktu maupun harganya.

3. Manajemen Kualitas Pembiayaan

Meskipun pengelola strategi operasional dari pinjaman adalah manajemen pembiayaan namun pengambilan keputusan operasional harus dijaga perkembangan serta kualitas pembiayaan sebagai penghasil utama aktivitas bank. Manajemen kualitas pembiayaan digunakan untuk menjaga kualitas pembiayaan sesuai dengan perencanaan. Dalam hal ini perlu adanya tim pengawas pembiayaan. Dalam hal pembiayaan Persetujuan pembiayaan hanya dilakukan oleh pejabat yang mempunyai wewenang untuk memutuskan pembiayaan. Keputusan harus didasarkan pada penilaian terhadap keseluruhan pembiayaan yang akan dan sedang dinikmati pemohon secara bersamaan (Tanjung, 2016: 164).

\section{Aplikasi Manajemen Asset dan Liabilitas pada Bank Islam}

Penerapan aplikasi manajemen asset dan liability pada bank syariah adalah untuk meningkatakan produktivitas dan kinerja perusahanan, antara alain adalah:

4. Meningkatkan segmentasi DPK

Dalam usaha meningkatkan segmentasi DPK, perbankan syariah dapat melakukan peningkatan terhadap beberapa bidang misalnya peningkatan standarisasi pelayanan, sistem dan jaringan teknologi, aksesibilitas ysng mudah, cepat dan aman, serta meningkatkan jaingan baik dari sisi kantor maupun virtual office.

5. Penguatan segmentasi korporasi untuk meningkatkan pendapatan. 
Segmentasi korporasi merupakan satu segmen yang baik untuk dibidik oleh bank syariah, dimana segmentasi korporsi dapat ditingkatkan melalui optimalisasi giro yang aman dan memiliki aksesibilitas tinggi terhadap korporasi, sehingga mengahasilkan ekspektasi bagi hasil yang rendah tetapi jumlah yang didapatkan dari sisi DPK lebih besar.

\section{Peningkatan Fee Based Income}

Fee based income atau pendapatan berbasis jasa layanan tidak termaksuk yang dibagihasilkan ke nasabah DPK oleh karena itu bank syariah dapat menurunkan ekspektasi keuntungan dari sisi pembiayaan dan mentrasformasikan dalam bentuk fee based income.

7. Peningkatan peranan regulator

Perlunya peningkatan peran regulator dalam menggunakan jasa keuangan dari perbankan syariah,sehingga peranan bank syariah dapat lebih meningkat lagi. Hal ini dikarenakan danadana pemerintah maupun BUMN dapat menjadi sumber DPK yang potensial pada perbankan syariah, regulator juga dapat menjadi solusi atas kebutuhan sistem permodalan bagi bank syariah.

8. Peningkatan sistem akuntabilitas Peningkatan sistem akuntabilitas pada bank syariah dapat dilakukan dengan beberapa cara diantaranya : peningkatan SDM yang memiliki kompetensi dan perbankan syariah secara baik, penerapan manajemen resiko yang komprehensif, sistem laporan yang informatif dan bertanggung jawab,sistem audit syariah dan bisnis yang berintegritas, dan sosialisasi yang merata kepada setiap masyarakat.

Adapun komponen kebijakan ALMA perbankan syariah sama dengan komponen kebijakan yang dilakukan oleh perbankan konvensional, perbedaannya adalah pengambilan keuntungan dari perdagangan valas untuk memaksimalisasi laba perbankan, serta pengamatan terhadap fluktuasi bunga. Karena keduanya dianggap tidak sesuai dengan ketentuan syariah (Tanjung, 2016: 165-166).

Likuiditas bank syariah banyak bergantung pada :

a. Tingkat kelebihan (volatility) dari simpanan (deposito) nasabah

b. Kepercayaan pada dana-dana nonPLS

c. Kompetensi teknis yang berhubungan dengan peraturan stuktur liabilitas

d. Ketersediaan aset yang siap dikonversikan menjadi kas

e. Akses kepada pasar antar bank dan sumber dana lainnya, termasuk 
fasilitas lender of last resort dari bank sentral.Teknik duration gap manajament dapat diaplikasikan oleh bank islam,bukan dalam rangka menghindari risiko tingkat bunga, melainkan untuk mengatur cash flow atau mengendalikan likuiditasnya. Risiko gap muncul apabila pada suatu periode tertentu terjadi/ terdapat ketidak seimbangan antara interest rate maturity dari aset dan liabilitas sehingga pendapatan bank menjadi sensitif terhadap perubahan tingkat bagi hasil di pasar10 Dalam pengambilan keputusan yang dilakukan perusahaan atau bank syariah apakah positif gap atau negatif gap tergantung pada tiga hal, yaitu:

1. Prakiraan arah perkembangan tingkat bagi hasil

2. Tingkat keyakinan manajemen terhadap perkiraan tersebut

3. Hasrat bank untuk mengambil risiko jika tindakan yang diambil salah.

Di samping tiga hal di atas, dalam menetukan strategi gap perlu diperhatikan pula pengaruh besarnya gap terhadap posisi dan likuiditas bank. Strategi negatif gap yang ditetapkan sebagai antisipasi terhadap turunnya tingkat bagi hasil akan mengurangi likuiditas bank karena jatuh tempo aset akan lebih panjang daripada jatuh tempo liabilitasnya, dan hal itu akan menentukan kemampuan bank untuk meningkatkan daya tariknya kepada nasabah untuk menginvestasikan dananya melalui bank tersebut, yang berarti meningkatkan kualitas pengelolaan liabilitasnya. Kemampuan manajemen untuk melaksanakan fungsinya sebagai profesional investment manager akan sangat menetukan kualitas aset yang dikelolanya.

\section{METODE}

Penelitian ini tergolong Library Research, data di kumpulkan dengan mengutip dalam penelitian kepustakaan, penelusuran pustaka yang dilakukan lebih sekedar menyiapkan kerangka penelitian atau proposal guna memperoleh penelitian sejenis, memperdalam kajian teoritis ataupun mempertajam metodologi. Sifat penelitian ini adalah deskriptif kualitatif yaitu penelitian yang berusaha untuk menemukan pemecahan masalah yang ada sekarang berdasarkan data, dengan cara menyajikan, menganalisis, dan menginterpretasikan data. Pengumpulan data dilakukan dengan mengelompokkan literatur-literatur dalam kategori yang berhubungan dengan pembahasan. Data yang 
penulis kumpulkan selanjutnya diolah dengan menggunakan teknik analisis data kualitatif dengan cara deduktif, yaitu teknik analisis data yang mengambil hal yang bersifat umum, kemudian menyimpulkan kepada hal yang bersifat khusus.

\section{HASIL DAN KESIMPULAN}

Asset/ Liability Management adalah serangkaian tindakan dan prosedur yang dirancang untuk mengontrol posisi keuangan. Isu-isu keamanan dan kesehatan merupakan bagian penting dari definisi ini. Hasil akhir dari manajemen aset/ liabilitas itu akan bermuara kepada kemampuan untuk menutup kerugian dan menyediakan kecukupan modal, pendapatan yang semakin baik serta kualitas dan komposisi pendatan bersih semakin baik. Kemampuan bank syariah dalam mengelola asset dan liabilitasnya akan mempengaruhi kulaitas perusahaan, yang juga akan mempengaruhi citra atau nama baik bank tersebut yang merupakan daya tarik nasabah untuk menginvestasikan dananya ke bank syariah.

$\begin{array}{ccr}\text { Strategi } & \text { ALMA } & \text { yang } \\ \text { digunakan bank } & \text { syariah adalah }\end{array}$

perencanaan, manajemen dana dan manajemen kualitas pembiayaan. Kemampuan bank syariah tersebut dalam mengelola aset dan liabilitasnya dapat dilihat dari kemampuan bank syariah dalam meningkatkan segmentasi Dana Pihak Ketiga, penguatan segmentasi korporasi untuk meningkatkan pendapatan, peningkatan fee based income, peningkatan peranan regulator, dan peningkatan sistem akuntabilitas. kemampuan bank syariah tersebut dalam mengelola aset dan liabilitasnya merupakan implementasi dari kesanggupan bank syariah tersebut dalam meminimalisir biaya-biaya dan risiko yang dapat terjadi, seperti : Financing risk yang merupakan kemempauan bank syariah dalam mengeloladebitur untuk memenuhi kewajibannya (keterlambatan angsuran atau pelunasan) tepat pada waktunya; Liquidity risk, yaitu risiko bahwa bank tidak dapat memenuhi kewajibannya pada waktunya atau hanya dapat memenuhi kewajiban melalui pinjaman darurat (bagi hasil yang tinggi) dan atau menjual aktivanya dengan harga yang rendah; Pricing risk, yang merupakan risiko kerugian dengan akibat perubahan tingkat bagi hasil, menentukan bentuk penurunan margin dari penanaman atau kerugian sebagai 
akibat menurunnya nilai aktiva. Risiko ini sebagai akibat Net Interest Margin atau tidak terpenuhinya likuiditas, atau terjadinya gap karena tidak tepatnya perhitungan pricing atas aset dan liabilitas; Foreign exchange risk, yaitu risiko kerugian sebagai akibat perubahan tingkat kurs terhadap "open position" karena adanya pergerakan kurs yang merugikan; Gap risk, yaitu risiko kerugian dari ketidakseimbangan interest rate maturity sehingga pendapatan bank menjadi sensitif terhadap perubahan tingkat bagi hasil di pasar; dan Kontinjen risk, yang merupakan risiko yang timbul sebagai akibat transaksi kontinjen, seperti bank garansi dan kontrak valuta asing berjangka.

Apabila bank syariah mampu memaksimalkan keuntungannya dari funding dan financing yang terkelola dengan baik dan terstruktur serta mampu menghasilkan pengelolaan risikorisiko yang dihadapi bank syariah secara optimal, maka bank syariah tersebut dapat dikatakan berhasil dalam stategi manajeman aset dan liabilitasnya.

\section{KEPUSTAKAAN ACUAN}

Karim, Adiwarman. 2010. Bank Islam: Analisis Fiqih dan Keuangan.
Jakarta: PT. Raja Grafindo Persada.

Ahmad Iqbal Tanjung. 2016. Strategi Manajemen Asset dan liabilitas dalam Perbankan Syariah.

Medan: Jurnal At-Tijaroh Volume 2, No. 2,

Dahlan Siamat. 1999. Manajemen Lembaga Keuangan. Jakarta: Lembaga Penerbit FEUI. Muhammad Syafii Antonio. 2001. Bank Syariah dari Teori ke Praktik. Jakarta: Gema Insani. Sri Susilo, dkk. 2000. Bank dan Lembaga Keuangan Lain. Jakarta: Salemba Empar

Veithzal Rivai, MBA, dkk. 2007. Bank and Financial Institution Management. Jakarta: PT Raja Grafindo Persada.

Veithzal Rivai, MBA dan Ir. H. Arviyan Arifin. 2010. Islamic Banking. Jakarta: Bumi Aksara. 